\title{
Evidence for the Historical Occurrence of Wolves (Canis spp.) in Nova Scotia, Canada
}

\author{
ANDREi N. WhitAKER ${ }^{1,2}$ and KAREN F. BEAZley ${ }^{1,3}$ \\ ${ }^{1}$ School for Resource and Environmental Studies, Faculty of Management, Dalhousie University, 6100 University Avenue, \\ Halifax, Nova Scotia B3H 4R2 Canada \\ ${ }^{2}$ Current address: Johns Southward Glazier Walton \& Margetts L.L.P., \#204-655 Tyee Road, Victoria, British Columbia \\ V9A 6X5 Canada \\ ${ }^{3}$ Corresponding author: karen.beazley@dal.ca
}

Whitaker, Andrei N., and Karen F. Beazley. 2017. Evidence for the historical occurrence of wolves (Canis spp.) in Nova Scotia, Canada. Canadian Field-Naturalist 131(1): 32-36. https://doi.org/10.22621/cfn.v131i1.1775

Although once common across the entire North American continent, wolves (Canis spp.) have been extirpated from most of their former territory. The historical occurrence and persistence of wolves in Nova Scotia has been a subject of debate because of comments on the wolf's rarity in early settler accounts and the absence of physical specimens. By consulting historical documents of European settlers, the Mi'kmaw lexicon, and fur trade records, we found evidence for the presence of a wolf population in Nova Scotia (which included the territory of New Brunswick before 1784) at European contact and persisting until the early 20th century.

Key Words: Historical distribution; wolves; Canis lycaon; Canis lupus; anecdotal evidence; Maritime Provinces

\section{Introduction}

The story of the wolf (Canis spp.) in North America is inextricably linked to the story of European colonization. As settlers displaced and replaced wild ungulates and other prey, wolves turned to the herds of colonial livestock as a food source (McIntyre 1995; Steinhart 1996). As colonists relied heavily on their stock for survival, they implemented a bounty system to try to eliminate the wolf from areas surrounding their settlements (McIntyre 1995; Steinhart 1996; Robinson 2001). The bounties, coupled with overall habitat degradation from human expansion and resource development, caused the wolf to be eradicated from roughly half its range, including the Canadian Maritime Provinces, by the middle of the 20th century (Carbyn 1987). It is believed wolves were eliminated from the Maritime Provinces sometime within the last quarter of the 19th century (Smith 1940; Carbyn 1987; Hayes and Gunson 1995; Lohr and Ballard 1996), although estimates of the timing vary from the mid-1860s (Gilpin 1867; Ganong 1908) to the early 20th century (Sheldon 1936).

The taxonomy of wolves in eastern North America is controversial. The wolf species that inhabited eastern Canada and the northeastern United States is generally known as the Eastern Wolf or the Eastern Timber Wolf (Canis lycaon) and also as the subspecies C. lupus lycaon (Nowak 1983, 1995; Rutledge et al. 2012). However, it is difficult to conclude whether $C$. lycaon, $C$. lupus, or subspecies of the latter inhabited the region because of the absence of physical specimens. Although it is certain that past canids were not Coyotes $(C$. latrans), which were not resident in the Maritime Provinces until the 1960s (Forbes et al. 2010), the taxonomic identity of the wolf that historically occurred in Nova Scotia is unclear.
While wolves were historically documented in the region, some authors have questioned whether the Maritimes supported a self-sustaining population (Ganong 1908; Lohr and Ballard 1996); based on comments in early settler accounts on the wolf's rarity, some have even doubted the existence of a resident wolf population in Nova Scotia altogether (Dodds et al. n.d.). In this study, we investigated European settler accounts, Mi'kmaw evidence, and fur trade records to determine the grounds for a historical Nova Scotian wolf population.

\section{Methods}

We conducted a literature search to find evidence of wolves in historical documents pertaining to Nova Scotia (Figure 1), which, until 1784, included the territory that became New Brunswick. As Nova Scotia was occupied by the Mi'kmaq, French, and English, there are historical accounts in all three languages; however, only original English documents and those translated into English were consulted. This limitation poses the risk of excluding important Mi'kmaw and French sources and is, thus, likely to result in a conservative account of wolf presence. In addition to the literature search, we also examined trapping statistics from the Dominion Bureau of Statistics (now Statistics Canada) and fur trade reports from the United Kingdom and the French settlement of Louisburg (an important shipping port on Cape Breton Island, Nova Scotia, during the period of French occupation and rule).

\section{Results and Discussion}

Evidence from the $M i{ }^{\prime} \mathrm{kmaq}$

The earliest evidence for the existence of wolves in Nova Scotia is found in the folklore and cultural history

A contribution towards the cost of this publication has been provided by the Thomas Manning Memorial Fund of the Ottawa Field-Naturalists' Club. 


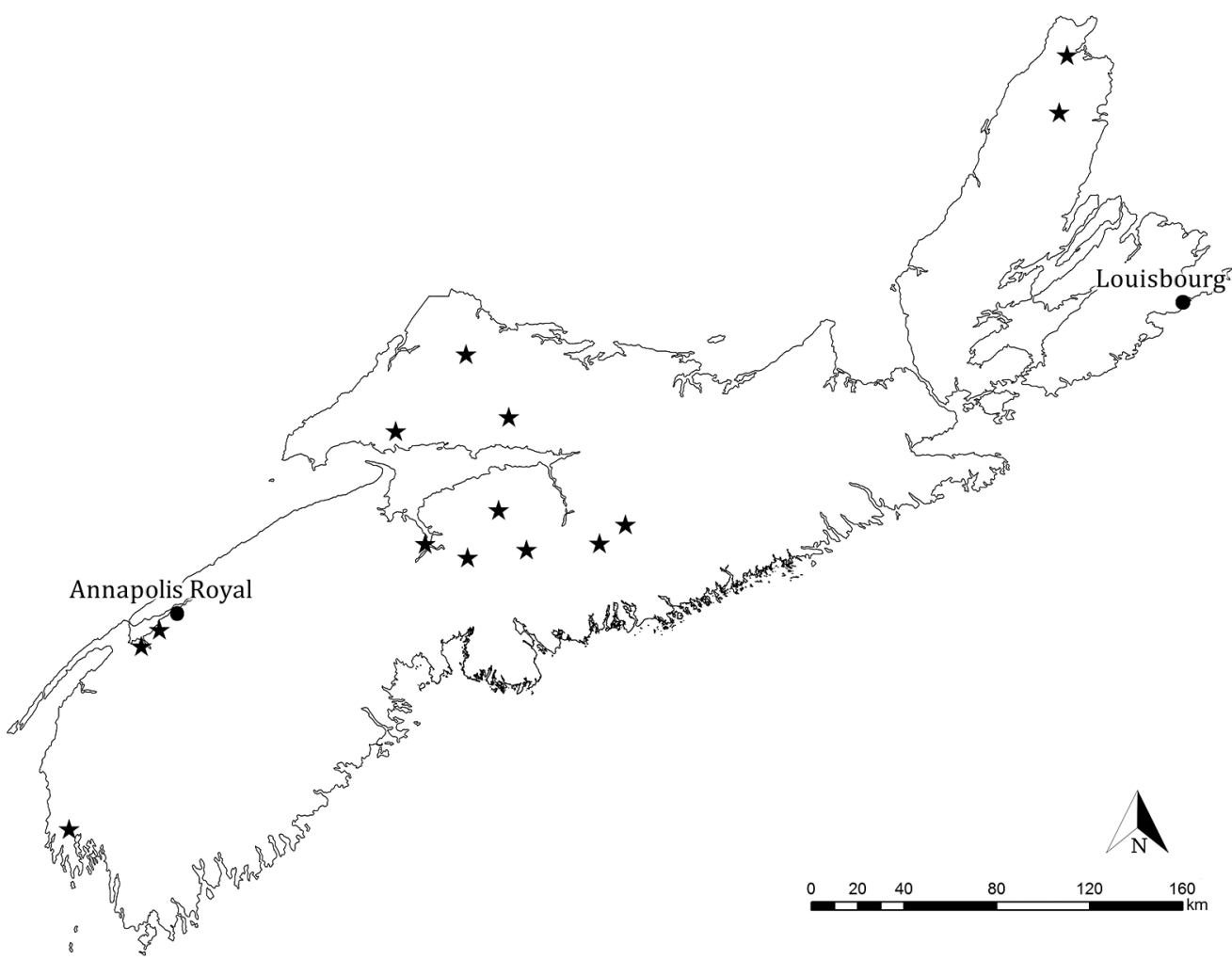

FIGURE 1. Historical occurrences of wolves (stars) in the area of the present-day province of Nova Scotia, as recorded in literary sources, 1606-1905.

of the Mi'kmaq. Archaeological digs at pre-contact Mi'kmaw sites in eastern Nova Scotia have yielded wolf remains (Ricker 1997). The early Mi'kmaw lexicographer, Reverend Silas T. Rand, gives the Mi'kmaw word for wolf as "bŏktŭsǔm" (Rand 1875, 1888) and notes that the language had an adjective, "bŏktŭsŭmooa", for describing someone or something as wolfish (Rand 1888). The wolf is also present in Mi'kmaw legends, often portrayed as a companion to the guardian Gluskap (Hardy 1855a; Rand 1894; Wallis and Wallis 1995).

\section{Evidence from Settlers}

The wolf is mentioned in writings from the beginning of French settlement in what is now Nova Scotia, in the Port Royal/Annapolis Royal region (Lescarbot 1609, 1914). In 1609, Lescarbot described wolves as being present in the region and noted that a neighbouring chief's name carried the meaning of wolf (Lescarbot 1914). When describing the food habits of the native population, he observed "[a]s for beafts of the woods they eate all of them, the woolfe excepted [sic]" (Lescarbot 1609: 212) and stated "I will not ftand to fpeake of woolues (for they haue fome, and yet eat none of them) [sic]" (Lescarbot 1609: 255). Soon after the French settled at Port Royal (now Annapolis Royal),
Jesuit missionaries were sent to New France (now Nova Scotia). In a letter of 1612, Father Biard made reference to the occurrence of the wolves around Port Royal while remarking upon the language gap between the Europeans and the local Mi'kmaq, writing, "They will name to you a wolf, a fox, a squirrel, a moose, and so on to every kind of animal they have" (Biard 1896: 11).

In 1794, the concern over wolves harassing sheep was great enough for a bill to be passed in the provincial legislature promoting their elimination (Table 1; 34 Geo III c II). Then, two years later, another Act was passed to encourage the destruction of wolves and other predators in response to damages they had wrought (Table 1; 36 Geo III c XVII). This Act was resurrected again in 1801 because of the continuing harm these animals were causing to livestock in Nova Scotia (Table 1; 41 Geo III c VII).

Sir George Head (1829: 42) reported that in Nova Scotia "wolves... are in sufficient numbers through all parts of the forests". Gesner $(1847,1849)$ writes that in the mid-1840s wolves were seen near Halifax and captured in the neighbourhoods of Windsor and Musquodoboit. At roughly the same time, Gilpin (1867: 12) observed that wolves were "in every part of the province... from north to the extreme south". In 1845, wolf 
TABLE 1. Nova Scotia legislation promoting wolf bounties, 1794-1851.

\begin{tabular}{|c|c|c|}
\hline Year & Duration & Title of Statute \\
\hline 1794 & None stated & An Act for the preservation of Sheep, S.N.S. 1794 (34 Geo III), c II \\
\hline 1796 & July 11797 & $\begin{array}{l}\text { An Act to encourage the killing of Wolves, Bears, Loup Cerviers, and Wild Cats, S.N.S. } \\
1796 \text { ( } 36 \text { Geo III), c XVII }\end{array}$ \\
\hline 1801 & Three years & $\begin{array}{l}\text { An Act to revive, and continue, an Act made in the thirty-sixth year of his Majesty's reign, } \\
\text { entitled, An Act to encourage the killing of Wolves, Bears, Loup Cerviers, and Wild Cats, } \\
\text { S.N.S. } 1801 \text { ( } 41 \text { Geo III), c VII }\end{array}$ \\
\hline 1845 & None stated & An Act to encourage the Killing of Wolves, S.N.S. 1845 (8 Vic), c XLVII \\
\hline 1846 & None stated & An Act to amend the Act to encourage the Killing of Wolves, S.N.S. 1846 (9 Vic), c XVII \\
\hline 1851 & Repealed by 1884 & Of The Destruction of Noxious Animals, R.S.N.S. 1951 (14 Vic), c 93 \\
\hline
\end{tabular}

bounties were revived by the province after a 40 year absence (Table 1; 8 Vic c XLVII) and continued to the latter years of the century. In 1885, the authority for granting wolf bounties was transferred from the province to the municipalities (An Act to amend Chapter 56 of the Revised Statutes, Fifth Series, "Of County Incorporations", S.N.S. 1885 c 13).

\section{Evidence from Fur Trade Records}

Trade in wolf skins is first mentioned in the sparse importation accounts, present only from a few years in the early 1740 s, of the French colony of Louisburg on Cape Breton Island. Between 1740 and 1743, 22 wolf pelts were brought into Louisburg from Nova Scotia (Gwyn 2003). As this number reflects only pelts brought to Louisburg on trading ships, it is likely that the number of wolf skins traded at the fort during this period was higher (K. Donovan, personal communication, 2006). In addition, the account books from suppliers Simonds and White from the area surrounding the Saint John River, New Brunswick, also list "two Nova
Scotia wolf' among the furs traded southward from 1764 to 1774 (Raymond 1943: 158).

The Nova Scotia fur trade also extended across the Atlantic to the United Kingdom. The London Custom House records show that the first wolf pelt from Nova Scotia was exported in 1753. From this year onward, wolf skins were steadily exported until 1867, the last year they are recorded. All in all, 1368 wolf skins were sent to England from Nova Scotia, for an average of 12 a year over 114 years (Table 2). Of these, only 10 wolf skins were exported during the period when New Brunswick was part of Nova Scotia (until 1784).

The final mention of the wolf is in the annual reports that the Dominion Bureau of Statistics began to publish after 1919. A total of 18 wolves were reported to be trapped in Nova Scotia in the 1919-20 season, and a further 10 wolves were harvested in 1920-21 (Novak et al. 1987). No more wolves were trapped until the 1927-28 season, when a single wolf was collected; after this, no further wolves are reported from Nova Scotia (Novak et al. 1987).

TABLE 2. Records of wolf pelts exported from Nova Scotia and Cape Breton to the United Kingdom, 1745-1870.*

\begin{tabular}{lcccrr}
\hline \hline Year & No. pelts & Year & No. pelts & Year & No. pelts \\
\hline 1753 & 2 & 1801 & 2 & 1846 & 4 \\
1754 & 2 & 1805 & 29 & 1847 & 52 \\
1763 & 1 & 1809 & 3 & 1848 & 23 \\
1777 & 1 & 1816 & 24 & 1851 & 2 \\
1782 & 4 & 1817 & 80 & 1852 & 2 \\
1785 & 1 & 1818 & 1 & 1853 & 2 \\
1787 & 1 & 1819 & 66 & 1854 & 2 \\
1789 & 2 & 1820 & 1 & 1855 & 23 \\
1790 & 1 & 1822 & 344 & 1856 & 15 \\
1791 & 1 & 1830 & 1 & 1859 & 200 \\
1792 & 1 & 1831 & 13 & 1862 & 1 \\
1793 & 5 & 1834 & 1 & 1863 & 89 \\
1794 & 1 & 1837 & 2 & 1864 & 83 \\
1795 & 1 & 1838 & 3 & 1865 & 20 \\
1797 & 4 & 1840 & 6 & 1866 & 124 \\
1800 & 1 & 1844 & 1 & 1867 & 120 \\
\hline \hline
\end{tabular}

Source: Inspector-General's Ledgers of Imports and Exports housed in the National Archives, Kew, England. Information retrieved by Dr. Julian Gwyn. In chronological order, the ledgers consulted were: CUST3/53, 3/54, 3/63, 3/77, 17/7, 17/8, 17/9, 17/10, 17/11, 17/12, 17/13, 17/14, 17/15, 17/16, 17/18, 17/22, 17/26, 17/30, 5/4, 5/5, 5/6, 5/7, 5/8, 5/10, 5/19, 5/20, 5/23, $5 / 26,5 / 27,5 / 29,5 / 33,5 / 35,5 / 37,5 / 39,5 / 45,5 / 47,5 / 49,5 / 51,5 / 53,5 / 61,5 / 67,5 / 69,5 / 73,5 / 77,5 / 83,5 / 89$.

*1813 data are missing as the London Custom House burned down that year and no trade data survived. Between 1757 and 1761, there were no fur exports from Nova Scotia to England. Until 1784, data may include furs from the territory that became New Brunswick. 


\section{Conclusion}

Although early naturalists observed that wolves were found across the entire North American continent, a few 19 th century writers believed that the wolf was not a resident species in the Canadian Maritimes region (Lohr and Ballard 1996). Gesner (1847) and Levinge (1846) claimed that wolves first entered New Brunswick in the 1800s in pursuit of White-tailed Deer (Odocoileus virginianus), and Gesner (1849) claimed that the wolf was not part of the "native" fauna of Nova Scotia. Hardy (1855b: 51) echoed this viewpoint when he noted that the wolf had "but lately made his appearance in Nova Scotia", as did Duvar (1867: 63) when he wrote that wolves in Nova Scotia were "rare visitor[s] from the adjoining province of New Brunswick".

The belief that wolves migrated into the province during the 19 th century may have been related to a probable increase in wolf-human interactions that occurred in the same period. The human population of Nova Scotia rose from 12000 in 1781 to 350000 in 1867 (Gesner 1849), which may have decreased the available habitat and prey populations for wolves, while increasing the likelihood of wolf observations through human expansion into former wolf territory. Our investigation shows that not only was the wolf present in Nova Scotia during the beginning of European settlement, but also that the animal was not extirpated until the 1920s. Although the evidence cannot tell us an overall population size, it does show that a persistent population of wolves did exist in Nova Scotia until the first quarter of the 20th century.

\section{Acknowledgements}

We thank J. Gwyn for information pertaining to the historical trade of wolf pelts from Nova Scotia and for generously providing personally retrieved data from England on Nova Scotia's fur trade with the United Kingdom. We also thank K. Donovan (Fortress of Louisbourg National Historic Site) for sharing his knowledge of 18th century fur trade at Louisburg. S. Toni contributed to the editing of this paper. Finally, we thank D. McAlpine, B. Patterson, and G. Forbes for guidance on wolf nomenclature.

\section{Literature Cited}

Biard, P. 1896. Letter from Father Pierre Biard to the Reverend Father Provincial, at Paris: Port Royal, January 31, 1612. Pages 5-56 in Jesuit Relations and Allied Documents: Travels and Explorations of the Jesuit Missionaries in New France, 1610-1792. Volume II: Acadia: 1612-1614. Edited by R. G. Thwaites. Burrows Brothers, Cleveland, Ohio, USA.

Carbyn, L. N. 1987. Gray wolf and red wolf. Pages 358377 in Wild Furbearer Management and Conservation in North America. Edited by M. Novak, J. A. Baker, M. E. Obbard, and B. Malloch. Ontario Ministry of Natural Resources, and Ontario Trappers' Association, Toronto, Ontario, Canada.

Dodds, D. F., E. Mullen, and A. Martell. n.d. Notes on rare and extinct carnivora of Nova Scotia. Unpublished paper. Nova Scotia Department of Lands and Forests, Kentville, Nova Scotia, Canada.

Duvar, J. H. 1867. Some additions to the game of Nova Scotia. Proceedings and Transactions of the Nova Scotia Institute of Natural Science 1: 59-69. http://hdl.handle.net $/ 10222 / 10117$

Forbes, G. J., D. F. McAlpine, and F. W. Scott. 2010. Mammals of the Atlantic Maritime Ecozone. Pages 693718 in Assessment of Species Diversity in the Atlantic Maritime Ecozone. Edited by D. F. McAlpine and I. M. Smith. NRC Research Press, Ottawa, Ontario, Canada.

Ganong, W. F. 1908. On the occurrence of the wolf in New Brunswick. Bulletin of the Natural History Society of New Brunswick 26: 30-35.

Gesner, A. 1847. New Brunswick: with Notes for Emigrants, Comprehending the Early History, an Account of the Indians, Settlement, Topography, Statistics, Commerce, Timber, Manufactures, Agriculture, Fisheries, Geology, Natural History, Social and Political State, Immigrants, and Contemplated Railways of that Province. Simmonds \& Ward, London, United Kingdom. https://catalog.hathitrust .org/Record/001971671

Gesner, A. 1849. The Industrial Resources of Nova Scotia: Comprehending the Physical Geography, Topography, Geology, Agriculture, Fisheries, Mines, Forests, Wild Lands, Lumbering, Manufactories, Navigation, Commerce, Emigration, Improvements, Industry, Contemplated Railways, Natural History and Resources of the Province. A \& W MacKinlay, Halifax, Nova Scotia, Canada. https:// catalog.hathitrust.org/Record/011614494

Gilpin, J. B. 1867. On the mammalia of Nova Scotia, no. II. Proceedings and Transactions of the Nova Scotian Institute of Natural Science 1: 8-15.

Gwyn, J. 2003. The Mi'kmaq, poor settlers, and the Nova Scotian fur trade, 1783-1853. Journal of the Canadian Historical Association 14: 65-91. https://doi.org/10.7202 /010320ar

Hardy, C. 1855a. Sporting Adventures in the New World, or, Days and Nights of Moose-Hunting in the Pine Forests of Acadia, Volume II. Hurst and Blackett, London, United Kingdom. https://catalog.hathitrust.org/Record/008628210

Hardy, C. 1855 b. Sporting Adventures in the New World, or, Days and Nights of Moose-Hunting in the Pine Forests of Acadia, Volume I. Hurst and Blackett, London, United Kingdom. https://catalog.hathitrust.org/Record/008628210

Hayes, R. D., and J. R. Gunson. 1995. Status and management of wolves in Canada. Pages 21-33 in Ecology and Conservation of Wolves in a Changing World. Edited by L. N. Carbyn, S. H. Fritts, and D. R. Seip. Occasional publication 35. Canadian Circumpolar Institute, Edmonton, Alberta, Canada.

Head, G. 1829. Forest Scenes and Incidents in the Wilds of North America: Being a Diary of a Winter's Route from Halifax to the Canadas, and During Four Months' Residence in the Woods on the Borders of Lakes Huron and Simcoe. John Murray, London, United Kingdom.

Lescarbot, M. 1609. Nova Francia: or the Description of that Part of New France, which is One Continent with Virginia. Translated by P. Erondelle. George Bishop, London, United Kingdom.

Lescarbot, M. 1914. The History of New France, Volume III. Translated by W. L. Grant. Champlain Society, Toronto, Ontario, Canada. https://doi.org/10.3138/9781442617865

Levinge, R. G. A. 1846. Echoes from the Backwoods: or Sketches of Transatlantic Life, Volume I. Henry Colburn, 
London, United Kingdom. https://doi.org/10.1017/cbo978 1139060387

Lohr, C., and W. B. Ballard. 1996. Historical occurrence of wolves, Canis lupus, in the Maritime Provinces. Canadian Field-Naturalist 110: 607-610.

McIntyre, R. 1995. Hunting their lost tribe. Pages 15-28 in War against the Wolf: American's Campaign to Exterminate the Wolf. Edited by R. McIntyre. Voyageur Press, Stillwater, Minnesota, USA.

Novak, M., M. E. Obbard, J. G. Jones, R. Newman, A. Booth, A. J. Satterthwaite, and G. Linscombe. 1987. Furbearer harvests in North America, 1600-1984. Pages 267-270 in Wild Furbearer Management and Conservation in North America. Edited by M. Novak, J. A. Baker, M. E. Obbard, and B. Malloch. Ontario Ministry of Natural Resources and Ontario Trappers' Association, Toronto, Ontario, Canada.

Nowak, R. M. 1983. A perspective on the taxonomy of wolves in North America. Pages 10-19 in Wolves in Canada and Alaska: Their Status, Biology, and Management. Edited by L. N. Carbyn. Canadian Wildlife Service report series 45 . Environment Canada, Ottawa, Ontario, Canada.

Nowak, R. M. 1995. Another look at wolf taxonomy. Pages 375-398 in Ecology and Conservation of Wolves in a Changing World. Edited by L. N. Carbyn, S. H. Fritts, and D. R Seip. Occasional publication 35. Canadian Circumpolar Institution, Edmonton, Alberta, Canada.

Rand, S. T. 1875. A First Reading Book in the Micmac Language: Comprising the Micmac Numerals, and the Names of the Different Kinds of Beasts, Birds, Fishes, Trees, \&c. of the Maritime Provinces of Canada. Nova Scotia Printing Company, Halifax, Nova Scotia, Canada.

Rand, S. T. 1888. Dictionary of the Language of the Micmac Indians, Who Reside in Nova Scotia, New Brunswick,
Prince Edward Islands, Cape Breton, and Newfoundland. Nova Scotia Printing Company, Halifax, Nova Scotia, Canada.

Rand, S. T. 1894. Legends of the Micmacs. Longmans, Green, and Company. New York, New York, USA.

Raymond, Rev W. O. 1943. The River St. John: Its Physical Features, Legends and History from 1604 to 1784. Tribune Press, Sackville, New Brunswick, Canada.

Ricker, D. A. 1997. L'stitkuk: the Story of the Bear River Mi'kmaw Community. Roseway Publishing, Lockeport, Nova Scotia, Canada.

Robinson, N. A. 2001. Tracking a new relationship: the wolf in New York law. Pages 97-107 in Wolves and Human Communities: Biology, Politics, and Ethics. Edited by V. A. Sharpe, B. G. Norton, and S. Donnelly. Island Press, Washington, DC, USA.

Rutledge, L. Y., P. J. Wilson, C. F. C. Klütsch, B. R. Patterson, and B. N. White. 2012. Conservation genomics in perspective: a holistic approach to understanding Canis evolution in North America. Biological Conservation 155: 186-192. https://doi.org/10.1016/j.biocon.2012.05.017

Sheldon, C. 1936. The mammals of Lake Kedgemakooge and vicinity, Nova Scotia. Journal of Mammology 17: 207-215. https://doi.org/10.2307/1374415

Smith, R. W. 1940. The land mammals of Nova Scotia. American Midland Naturalist 24: 213-241. https://doi.org/10 $.2307 / 2421063$

Steinhart, P. 1996. The Company of Wolves. Alfred Knopf, New York, New York, USA.

Wallis, W. D., and W. R. Wallis. 1955. The Micmac Indians of Eastern Canada. University of Minnesota, Minneapolis, Minnesota, USA.

Received 8 February 2016

Accepted 30 January 2017 